\title{
-Note- \\ Experimental Pulmonary Metastasis of Chinese Hamster Mesenchymal Chondrosarcoma Cell Lines
}

\author{
Nobuyoshi FUJISAWA, Norimitsu L. SATO, and Teiichi MOTOYAMA* \\ Institute for Laboratory Animals, and ${ }^{*} 1$ st Department of Pathology, Niigata University School of Medicine, \\ 1-757 Asahimachi-dori, Niigata-shi, Niigata 951, Japan
}

(Received 5 July 1994/Accepted 7 October 1994)

\begin{abstract}
Pulmonary metastases of chinese hamster mesenchymal chondrosarcoma cell lines, MCS-1 (undifferentiated type) and MCS-8 (differentiated type), were examined by intravenous transplantation into athymic nude mice.

The incidence of pulmonary metastasis of MCS-1 was $100 \%$ and that of MCS-8 was $33 \%$ at the 23rd day after transfer. Mean number of metastatic nodules in the lung was 41 in the former and only 3 in the latter. Mean survival time of mice with MCS- 1 injection $\left(5 \times 10^{4}\right.$ cells $)$ was 27 days and that with MCS- $8\left(5 \times 10^{4}\right.$ cells $)$ was 48 days after transfer. At the 42 nd day after transfer of MCS-8, however, the incidence of pulmonary metastasis was $100 \%$. These data suggest that the tumor growth rate in the metastatic lesion, as well as the affinity to the target organ, is very important for evaluation of experimental metastasis. -KEY WORDS: mesenchymal chondrosarcoma, metastasis, lung
\end{abstract}

\section{チャイニーズハムスター間葉型軟骨肉腫細胞株による実験的肺転移}

\author{
藤沢信義・佐藤德光・本山悌一* \\ 新潟大学医学部附属動物実験施設 \\ * 新潟大学医学部病理学第一講座
}

間葉型軟骨肉腫は, ヒトでも稀な腫瘍であるが, 未 分化な間葉細胞が増殖するなかに分化した軟骨島が形 成されるという特徽的な組織形態を示す $[5,12,16$, 18]。放射線療法や化学療法は著効なく, 外科的切除 後の局所再発や, 肺転移をきたしやすいとされている $[10,13,15]$ 。

我々は,チャイニーズハムスターの㚘袋部に自然発 生した間葉型軟骨肉腫から培養細胞株を樹立し,さら に幾つかのクローンを分離し、その特性を調べてき た。今回，既にその諸性格を明らかにしてある2種の クローン株 [8] を用い, ヌードマウスにおける実験的 肺転移を試み, その結果, 転移の評価に関する重要な 事柄を見出したので報告する。
供試動物：CD-1（ICR）系ヌードマウスの雄および 雌（6８週齢），計37匹を用いた。これらのマウスは 床敷（ホワイトフレーク，日本チャールスリバー）を 入れたプラスチックケージ（MT-1，W143×D293× H148 mm, 日本チャールスリバー) に3〜4匹収容し, ラミナフローラック内で飼育した。市販固型飼料 (CE-2, 日本クレア) と水道水をオートクレーブ滅菌 して自由椇取させた。照明は，12時間明 $(6: 00-18$ : $00) ， 12$ 時間暗（18:00６:00）とした。また室温は $23 \pm 2^{\circ} \mathrm{C}$ ，湿度は 40 一 $70 \%$ に維持した。

細胞の調整と移植: 未分化な軟骨肉腫細胞のみより なるMCS-1株と, in vitroで容易に分化し得る軟骨肉 腫細胞からなる MCS-8 株を 10\%牛胎仔血清加Eagle’s 
MEM で培養後, 同液に浮遊し, 各々 $5 \times 10^{4}$ 個 /匹を ヌードマウス尾静脈内に注射した。

転移率：直径 $0.5 \mathrm{~mm}$ 以上の転移結節を有するもの を転移陽性として転移率を調べると, 移植23日目で は, MCS-1 群では100\% (9/9), MCS-8群では33\% （3/9）であり，前者が有意に高かった（Table 1)。し かし, 後者の移植 42 日目における転移率は100\% （9/9）となり, 長期観察をすれば, 両者の転移率その ものには差がないことがわかった。

肺転移結節数: 実体顕微鏡下に観察されるすべての 転移結節を有柄針を用いて単離した後, 直径をノギス で計測した。直径 $0.5 \mathrm{~mm}$ 以上の平均結節数は, 移植 23 日目の観察でMCS-1 腫瘍群が 41 個 /肺, MCS-8 腫 瘍群が 3 個／肺と MCS-1 腫瘍群が有意に多かった (Fig. 1)。両細胞の肺転移巣における増殖速度の差を
考慮して, MCS-8 細胞移植 42 日目の肺転移結節を数 えたところ, 直径 $0.5 \mathrm{~mm}$ 以上の結節は平均 20 個 $/$ 肺 と増加していた。

肺転移巣の組織像：MCS-1 群の転移巣はすべて未分 化な腫瘍細胞から成っていた（Fig. 2)。他方, MCS-8 群の転移巣は, 顕微鏡的微小転移巣はすべて未分化な 腫瘍細胞から成っていたが, 大型になり, 特に直径 1 $\mathrm{mm}$ を超えるようなものでは全例腫瘍性軟骨芽細胞な いし軟骨細胞が含まれていた（Fig. 3)。

死亡までの日数: 静脈内に移植してから, 死亡する までの平均日数は, MCS-1 群で 27 日, MCS- 8 群で 48 日であった（Table 1)。死因はMCS-8群でみられた肝 転移による1例を除いて，すべて肺転移によるものと 考えられた。

これまで, 腫瘍の転移実験には, マウスのメラノー

Table 1. Experimental pulmonary metastases of MCS-1 and MCS- 8 cells

\begin{tabular}{lcc}
\hline & MCS-1 & MCS-8 \\
\hline Cell characteristics & Undifferentiated cell & $\begin{array}{c}\text { Capable of differentiation } \\
\text { to cartilagenous direction }\end{array}$ \\
$\begin{array}{c}\text { Incidence of pulmonary metastasis } \\
23 \text { days after i.v. injection } \\
42 \text { days after i.v. injection }\end{array}$ & $9 / 9(100 \%)^{\mathrm{b})}$ & $3 / 9(33.3 \%)^{*}$ \\
No. of metastatic nodules in the lung & $9 / 9(100 \%)$ \\
23 days after i.v. injection & - & $3 \pm 2(\mathrm{n}=6)^{* *}$ \\
42 days after i.v. injection & $41 \pm 22(\mathrm{n}=6)^{\mathrm{c})}$ & $20 \pm 16(\mathrm{n}=6)$ \\
Survival time (Days after i.v. injection) & - & $48 \pm 15(\mathrm{n}=7)^{* *}$ \\
\hline
\end{tabular}

a) Metastatic nodules $\geqq 0.5 \mathrm{~mm}$ in diameter. b)No. of mice with metastasis/examined. c)Mean \pm S.D.; Statistically significant differences between MCS -1 and MCS- 8 at $* \mathrm{p}<0.05$ by $\chi^{2}$-test, $* * \mathrm{p}<0.05$ by $\mathrm{t}-\mathrm{test}$.

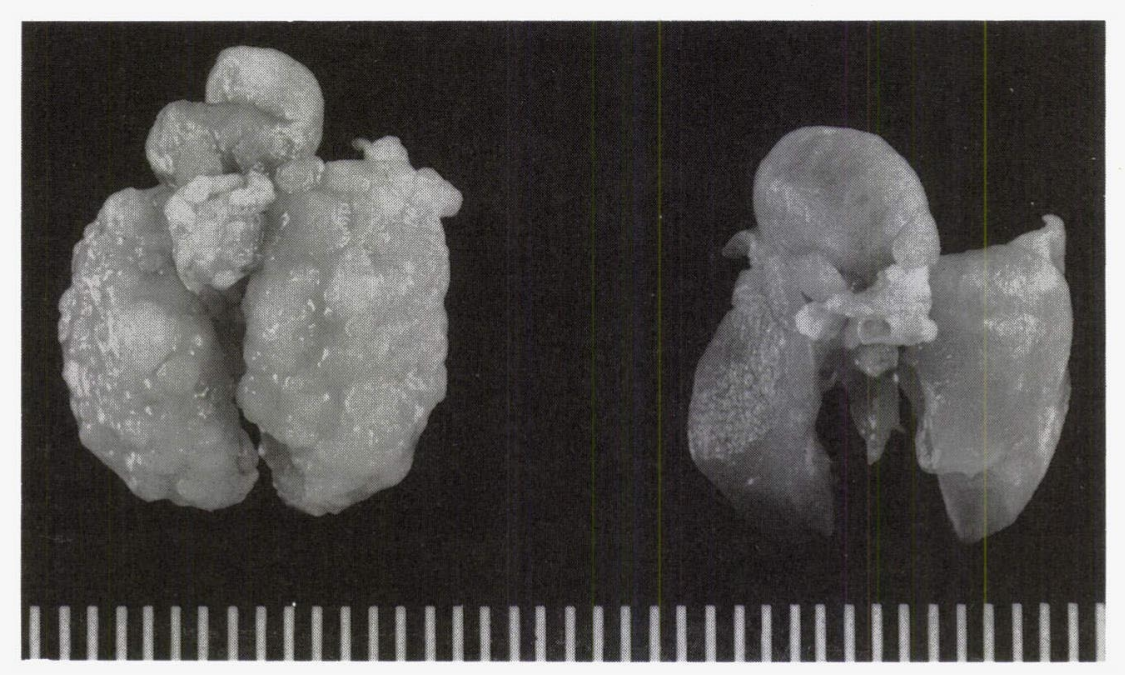

Fig. I. Macroscopic findings of metastasized lungs. MCS-1 cells formed far more metastatic nodules in the lung (left side) than did MCS-8 cells (right side). 
マ [6, 14], 線維肉腫 $[19,23]$, リンパ肉腫 [1], 乳

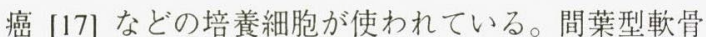
肉腫細胞を用いた転移実験は，われわれが知るかぎり 本報が最初である。

一般に,転移実験の評価のしかたには幾つかの問題 がある。連続組織切片の光顕による観察から求めるこ とは，時間もかかり繁雑であるため，これまでは実体 顕微鏡により肉眼的に肺表面に認められる結節を数え

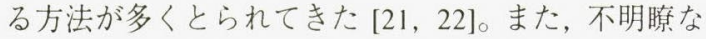
小結節を可視化するために, 肺実質を色素で染める方 法なども試みられている [21]。ほとんどの転移結節 は, 肺表面あるいは表面に近い部位にあるといわれて きたが [7，21]，本腫瘍では肺深部にも多数の結節が 存在していた。そのため，われわれは実体顕微鏡下に これらを有柄針で単離し転移結節数としたが，この方 法がより正確と考える。転移偽陽性結節の混入を防ぐ ため, 今回は直径 $0.5 \mathrm{~mm}$ 以上のもののみを数えたが, 直径 $0.5 \mathrm{~mm}$ 以下のものであっても単離可能なものは すべて数え, かつ，それらをすべて組織慓本化して確 認する万が，より正確であろう。

次に，転移能を比較する場合，腫瘍移植後のある時 点における転移結節数 [14，19] や, 肺重量の差 [19] で論じられることが多いが, MCS-8細胞のように肺に 生着した細胞が結節として視認し得る大きさに達する
までにかなりの時間を要するものも存在する。転移率 の評価は長期観察によってもなされるべきであろう。

Table 1 に示したように，短期観察ではMCS-8 細胞 の肺転移率は MCS-1 細胞と比べ著しく低いように見 えるが, 長期にわたって観察すると動物の数からみた 転移率には差のないことがわかる。このことは, 組織 学的検索結果を考慮すると，次のように2段階に分け て説明できる。形態的に分化した軟骨肉腫細胞は転移 能を欠いてしまうため, 尾静脈に注入されたMCS-8 細胞のすべてが転移に関与できるわけではない。つま り，同じ細胞数注入されても，転移に直接関われる細 胞数は MCS-1 細胞の方が多い。しかし, さらなる分 化能が有るか無いかにかかわらず，両細胞株の未分化 な形態をした細胞の転移能には著差は無いように思わ れる。したがって MCS-1 細胞に比べれば数は少ない ながらも MCS-8 細胞も肺に生着する。次に, 転移生 着後, MCS-1 細胞は分化能が無いため増殖が速く, MCS-8細胞は分化傾向を示すため増殖が遅い。以上の ことが短期観察における転移率の違いや死亡までの日 数の違いとして現れるものと考えられる。

一方, 腫瘍細胞の臓器選択性の存在が知られている [9，14，19]。MCS-8 群の中で।例のみ肝転移がみられ たが他はすべて肺転移のみであったので, 間葉型軟骨 肉腫細胞の主たる標的蔵器は肺であると考えられ, ヒ

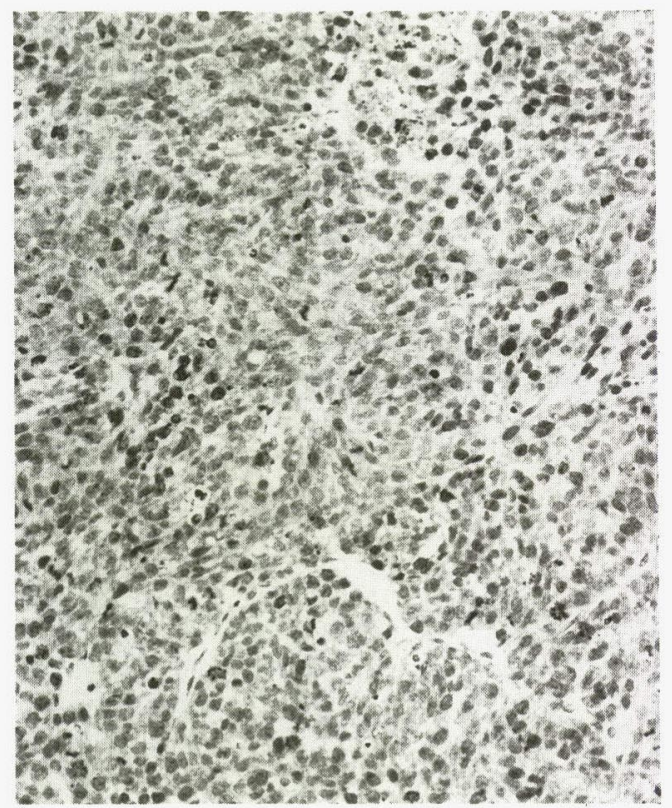

Fig. 2. Histologic findings of MCS-1 cell tumor in the lung. The tumor was composed of only undifferentiated cells. Hematoxylin-Eosin, $\times 170$.

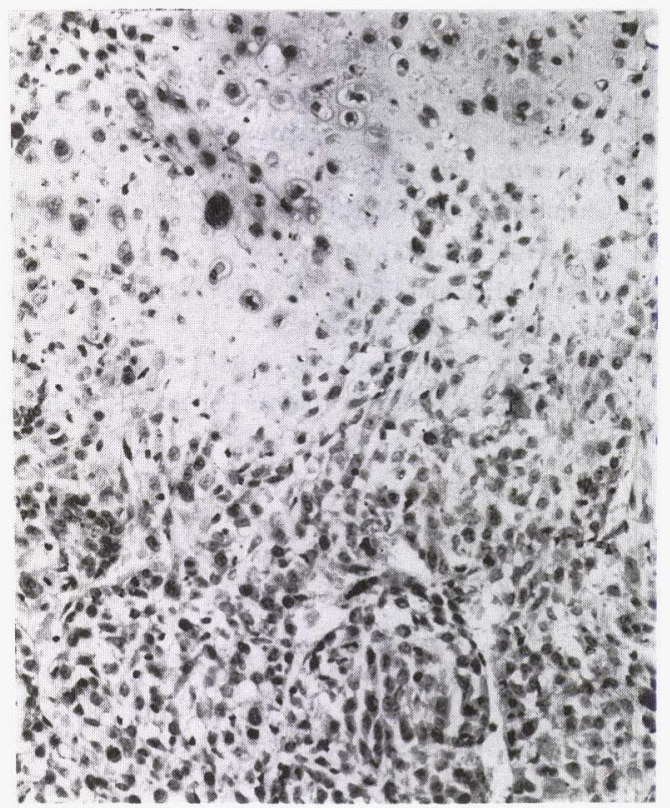

Fig. 3. Histologic findings of MCS-8 cell tumor in the lung. The tumor contained foci showing cartilagenous differentiation. HematoxylinEosin, $\times 170$. 
卜臨床例の実際とも合致する。これは, 肺が最初の フィルターとなるためかもしれない。チャイニーズ ハムスターの細胞を用いた肺転移実験としては, 他に Chadwickらが肺線維芽細胞株 CCL39 をヌードマウス に移植し, 自律増殖能と転移能の関倸を調べたものが ある [2]。しかし, 臨床的に実際に起っている事象を 問題にするとき，われわれの MCS 株細胞による実験 系はより有用であると思われる。

\section{要 約}

チャイニーズハムスター間葉型軟骨肉腫由来の 2 種 のクローン細胞株を用い, 実験的肺転移の病態を比べ た。末分化型細胞のみよりなる MCS-1 株と, 軟骨へ の分化能を持つ MCS-8 株において, ヌードマウス静 脈内移植 23 日目の転移率は，それぞれ 100\% と 33\%, 肉眼的転移結節数は平均 41 個と 3 個であった。また, 移植後生存日数は，それぞれ平均 27 日と 48 日であっ た。しかし, MCS-8 移植 42 日目には, その転移率も $100 \%$ となった。以上の結果から, 両者の転移像の相 違が明らかとなった。また, 転移能を論じるときは, 転移藏器への腫汮細胞生着率が問題となるが, その 際, 転移部位における腫瘍の增殖速度を特に考虑する 必要がある。

\section{文 献}

[1] Brunson, K.W. and Nicolson G.L. (1978). J. Natl. Cancer Inst., 61, 1499-1503.

[2] Chadwick, D.E. and Lagarde, A.E. (1988). J. Natl. Cancer Inst., 80, 318-325.

[3] Chambers, A.F., Hill, R.P., and Ling, V. (1981). Cancer Res., 41, 1368-1372.

[4] Cifone, M.A. and Fidler, I.J. (1981). Proc. Natl. Acad. Sci. USA, 78, 6949-6952.

[5] Dahlin, D.C. and Unni, K.K. (1986). In Bone Tumors, pp.260-268. Charles C. Thomas Publisher, Springfield.
Illinois.

[6] Fidler, I.J. and Kripke, M.L. (1977). Science, 197 , 893895.

[7] Fidler, I.J. (1978). Methods Cancer Res., 15, 399-439.

[8] Fujisawa, N., Sato, N.L., and Motoyama, T. (1991). Lab. Anim. Sci. , $41,590-595$.

[9] Hart, I.R., Talmadge, J.E., and Fidler, I.J. (1981). Cancer Res., $41,1281-1287$.

[10] Huvos, A.G., Rosen. G., Dabska. M.. and Marcove, R.C. (1983). Cancer, 51 , 1230-1237.

[11] Kripke, M.L., Gruys, E., and Fidler, I.J. (1978). Cancer Res., 38, 2962-2967.

[12] Lichtenstein, L. and Bernstein, D. (1959). Cancer, 12. 1142-1157.

[13] Evans, H.L., Ayala, A.G., and Romsdahl, M.M. (1977). Cancer, 40, 818-831.

[14] Nicolson, G.L., Brunson, K.W., and Fidler, I.J. (1978). Cancer Res., 38, 4105-4111.

[15] Salvador, A.H., Beabout, J.W., and Dahlin, D.C. (1971). Cancer, 28, 605-615.

[16] Shimo-oku, M., Okamoto. N., Ogita, Y., and Sashikata. T. (1980). Acta, Ophth., 58, 831-840.

[17] Takeda, K., Hatakeyama, K., Tsuchiya, Y., Rikiishi, H., and Kumagai, K. (1991). Int. J. Cancer, 47, 413-420.

[18] The JOA Musculo-skeletal Tumor Committee. (1990). General Rules for Clinical and Pathological Studies on Malignant Bone Tumors, pp.76-79, Kanehara Publishing Co., Tokyo.

[19] Tsuruo. T., Yamori, T.. Naganuma, K., Tsukagoshi, S.. and Sakurai, Y. (1983). Cancer Res., 43, 5437-5442.

[20] Wang, N., Yu, S.H., Liener , I.E., Hebbel, R.P., Eaton, J.W., and Mckhann. C.F. (1982). Cancer Res., 42 , 1046 -1051 .

[21] Wexler, H. (1966). J. Natl. Cancer Inst, 36, 641- 645.

[22] Wood, J.S.. Jr., Holyoke, E.D., Clason, W.P.C.. Sommers, S.C., and Warren. S. (1954). Cancer, 7, 431433.

[23] Yamori, T., Iida, H., Tsukagoshi, S., and Tsuruo, T. (1988). Clin. Expl. Metastasis, 6, 131-139. 